\title{
Cryptococcal meningitis in steroid-treated systemic lupus erythematosus
}

\author{
M. Anees Khan \\ M.D.
}

\author{
SIDNEY SBAR \\ M.D.
}

\section{The Department of Internal Medicine, Veterans Administration Hospital, 800 Poly Place, Brooklyn, New York 11209}

\begin{abstract}
Summary
A case of cryptococcal meningitis complicating steroidtreated systemic lupus erythematosus (SLE) which was successfully treated with amphotericin B is described.

Although apparently rare, this mycotic infection has been reported from six patients with SLE in the medical literature over the past 10 years. Four of the six had been treated with steroids for periods ranging from 10 weeks to 6 years. In only one of these was the fungal infection diagnosed and effectively treated. Because effective therapy is available it is imperative that cryptococcal meningitis be not confused with progressive central nervous system involvement of SLE.
\end{abstract}

\section{Introduction}

Opportunistic infections by fungal, bacterial, viral, and protozoal organisms are being reported in everincreasing frequency. Of the mycotic infections, aspergillosis, candidiasis, mucormycosis, histoplasmosis, nocardiasis and cryptococcosis have been implicated. Patients with lymphoproliferative and immune deficiency disorders such as Hodgkin's disease, other lymphomas, leukaemias, multiple myeloma, primary and acquired agammaglobulinaemia and even Boeck's sarcoid seem particularly vulnerable. This susceptibility seems to derive primarily from a defective defence mechanism which characterizes these diseases, but in our current era of aggressive and intensive therapy, their treatment with immunosuppressive agents, e.g. corticosteroids, cytotoxic drugs and ionizing radiation, encourages these unusual, serious complicating infections. In this context SLE may also be viewed as a disease of abnormal immune reactivity and tolerance, and its increased susceptibility to opportunistic fungal infections, particularly when accentuated by steroid therapy, should not be surprising.

\section{Case report}

\section{A 41-year-old, black school teacher, recently}

Reprint request to: Dr M. Anees Khan, Pulmonary Division, Boston University School of Medicine, Boston City Hospital, 818 Harrison Ave, Boston, Mass. 02118, U.S.A. arrived from his home in Georgia, was admitted to the Brooklyn V.A. Hospital in November 1972 for evaluation of generalized weakness, weight loss, arthralgias, anorexia and cough. Five months previously, he had presented himself at a local hospital with polyarthralgia, where a diagnosis of systemic lupus erythematosus was made and therapy with prednisone $(20 \mathrm{mg}$ daily) was initiated. At the time of admission, he appeared as an oriented, alert asthenic, emaciated anaemic, afebrile man in no acute distress, with a blood pressure of $90 / 60$ $\mathrm{mmHg}$. Besides flexion deformities of second and third distal interphalangeal joints of both hands and oro-pharyngeal moniliasis, physical examination was unremarkable. He had no papilloedema, neck stiffness or other neurological abnormalities. The diagnosis of SLE was confirmed by repeated demonstration of LE cells, hypocomplementaemia $\left(39^{\circ}\right.$ $\mathrm{mg} \%$ ) hypergammaglobulinaemia, positive antinuclear antibody and microscopic haematuria. Chest $\mathrm{X}$-ray was normal. Sputum smears and cultures were repeatedly negative for fungi. He was maintained on $20 \mathrm{mg}$ prednisone daily, while initial investigations were carried out. One week after admission he began to have low grade fever without headache or neck stiffness. Three weeks later he developed mental confusion and neck rigidity, followed within hours by a grand mal seizure. Spinal tap revealed clear straw coloured fluid under $200 \mathrm{mmH}_{2} \mathrm{O}$ pressure with $1000 \mathrm{WBC} / \mathrm{mm}^{3}(\mathrm{P}=82 \%, \mathrm{~L}, 13 \%)$, protein, $268 \mathrm{mg} \%$, glucose, $38 \mathrm{mg} \%$. Gram stain showed many yeast cells which on staining with India ink resembled Cryptococcus neoformans.

This was soon confirmed by culture. AmphotericinB therapy was instituted in an initial dose of $10 \mathrm{mg}$ dissolved in $400 \mathrm{cc}$ of $5 \%$ dextrose in water with $40 \mathrm{mg}$ hydrocortisone and $1000 \mathrm{u}$ heparin i.v. infusion over a period of $6 \mathrm{hr}$. Therapy was continued on alternate day basis, increasing the dose by $10 \mathrm{mg}$ each time during the first week, and later by $5 \mathrm{mg}$ until the maximum dose of $35 \mathrm{mg}(0.75 \mathrm{mg} / \mathrm{kg})$ was reached. By using alternate limb veins for each infusion, no local complications of therapy were encountered. One week after initiation of therapy, the patient was able to communicate and to consume liquids. Head- 
TABLE 1. Sequential CSF analysis data after treatment with amphotericin-B. (Therapy ended 6 April 1973)

\begin{tabular}{|c|c|c|c|c|c|c|c|}
\hline Date & Colour & $\begin{array}{c}\text { Cell } \\
\text { count } \\
\text { per HPF }\end{array}$ & $\begin{array}{l}\text { Glucose } \\
(\mathrm{mg} \%)\end{array}$ & $\begin{array}{l}\text { Protein } \\
(\mathrm{mg} \%)\end{array}$ & $\begin{array}{l}\text { India ink } \\
\text { preparation }\end{array}$ & $\begin{array}{c}\text { Culture } \\
\text { for } \\
\text { C. neoformans }\end{array}$ & $\begin{array}{c}\text { Antibody } \\
\text { test }\end{array}$ \\
\hline $\begin{array}{l}\text { April } 1973 \\
\text { August } 1973 \\
\text { April } 1974\end{array}$ & $\begin{array}{l}\text { Clear } \\
\text { Clear } \\
\text { Clear }\end{array}$ & $\begin{array}{c}5 \text { lymphocytes } \\
\text { None } \\
\text { None }\end{array}$ & $\begin{array}{c}35 \\
23 \\
\text { Normal }\end{array}$ & $\begin{array}{r}136 \\
57 \\
19\end{array}$ & $\begin{array}{l}\text { neg. } \\
\text { neg. } \\
\text { neg. }\end{array}$ & $\begin{array}{l}\text { neg. } \\
\text { neg. } \\
\text { neg. }\end{array}$ & $\begin{array}{l}\text { neg. } \\
\text { neg. } \\
\text { neg. }\end{array}$ \\
\hline
\end{tabular}

TABLE 2. Analysis of 7 SLE cases complicated $\bar{c}$ cryptococcal meningitis

\begin{tabular}{|c|c|c|c|c|c|c|c|}
\hline Series & $\begin{array}{c}\text { No. } \\
\text { of } \\
\text { cases }\end{array}$ & $\begin{array}{l}\text { Age } \\
\text { and } \\
\text { sex }\end{array}$ & $\begin{array}{l}\text { Immuno- } \\
\text { suppressive } \\
\text { therapy }\end{array}$ & $\begin{array}{l}\text { Duration of } \\
\text { immuno- } \\
\text { suppressive } \\
\text { therapy }\end{array}$ & $\begin{array}{l}\text { Diagnosed } \\
\text { ante mortem }\end{array}$ & $\begin{array}{l}\text { Diagnosed } \\
\text { post mortem }\end{array}$ & $\begin{array}{l}\text { Outcome } \\
\text { of therapy } \\
\text { if given }\end{array}$ \\
\hline 1. Pillay et al. (1968) & 1 & $\begin{array}{c}11 \\
\text { Female }\end{array}$ & Steroids & 6 years & No & Yes & - \\
\hline $\begin{array}{l}\text { 2. Rapaport, Ames and } \\
\text { Duvall (1960) }\end{array}$ & 1 & $\begin{array}{c}11 \\
\text { Female }\end{array}$ & Steroids & $\begin{array}{l}\text { Several } \\
\text { months }\end{array}$ & No & Yes & - \\
\hline 3. Collins et al. (1971) & 1 & $\begin{array}{c}26 \\
\text { Female }\end{array}$ & $\begin{array}{c}\text { Prednisone } \\
\text { and } \\
\text { azathioprine }\end{array}$ & 10 weeks & No & Yes & - \\
\hline 4. Collins et al. (1972) & 1 & $\begin{array}{c}46 \\
\text { Female }\end{array}$ & Prednisone & 3 years & Yes & - & Successful \\
\hline 5. Pariser et al. (1961) & 1 & $\begin{array}{c}50 \\
\text { Female }\end{array}$ & None & - & No & Yes & - \\
\hline $\begin{array}{l}\text { 6. Case Record MGH } \\
(1961)\end{array}$ & 1 & $\begin{array}{c}40 \\
\text { Female }\end{array}$ & None & - & No & Yes & - \\
\hline 7. Present report & 1 & $\begin{array}{c}41 \\
\text { Male }\end{array}$ & Prednisone & 5 months & Yes & - & Successfy \\
\hline
\end{tabular}

ache and nuchal rigidity had disappeared. Three weeks after initiating therapy, temperature was near normal and spinal tap showed acellular fluid under $160 \mathrm{mmH}_{2} \mathrm{O}$ pressure. Although protein content was still elevated, India ink preparation and cultures for $C$. neoformans were now negative. Creatinine clearance obtained before each treatment initially and once a week subsequently showed moderate impairment which did not deteriorate below $70 \mathrm{cc} / \mathrm{min}$. The initial few weeks of therapy were attended with elevation of LDH and alkaline phosphatase to levels of $515 \mathrm{u}$ and $275 \mathrm{u}$ respectively (with normal bilirubin) followed by a slow fall towards normal even as treatment with amphotericin was continued.

The patient received a total of $1 \mathrm{~g}$ amphotericin-B over a 4-month period. This resulted in complete remission of constitutional and neurological symptoms, allowing him to return to work. Since discontinuation of therapy, three spinal taps (Table 1) have failed to document any residual infection. This would seem to attest to the adequacy of a relatively small dose of amphotericin-B in eradicating infection in this patient, perhaps because of his low body weight $(90 \mathrm{lb})$. The recommended total dose of about $3 \mathrm{~g}$ should be adhered to in standard situations.

\section{Discussion}

Cryptococcal involvement of the central nervous system (CNS) is usually insidious in onset producing signs and symptoms of meningitis, meningoenceph通 기 litis, or a space-occupying lesion. Headaches a generally followed by slowly progressive malaise, depression, disorientation and fever with eventual appearance of nausea, vomiting, nuchal rigidity and other manifestations of elevated intracranial tension. Untreated cryptococcal meningitis usually terminates fatally within several months, although chronic infection lasting many years has been described.

The incidence of cryptococcal meningitis is relatively high in patients with Hodgkin's disease, lymphoma, leukaemia, diabetes mellitus, and also in those on long-term steroid therapy (Zimmerman and Rappaport, 1954). That $C$. neoformans is not an infrequent culprit in the aforementioned diseases is also attested to by Goldstein and Rambo's (1962) report of 286 cryptococcal infections. Almost $10 \%$ of their cases had reticuloendothelial malignancies and $5.4 \%$ had had prior steroid therapy. On the other hand, complete absence of cryptococcal infection in an analysis of 520 cases of SLE by Dubois N and Tuffanelli (1964) and the report of only one such N complication in Harvey's 138 SLE cases (Harvey, 1954) leads one to conclude that this mycotic disease is a rather rare development in this setting. Nevertheless, we have been able to find six previously reported cases of SLE with this infection, summarized in Table 2.

In our perusal of the literature, we also found 
reference to several other patients with cryptococcal infection in which background clinical features suggested active SLE. Failure to perform LE preparation, etc., indicates that the diagnosis was not given serious consideration. Nicholas and Martin in 1955 described such a case in a 16-year-old girl with fever, headache, malar flush, generalized lymphadenopathy, leukopenia, microscopic haematuria and EKG changes suggestive of pericarditis. At postmortem examination 6 weeks later disseminated cryptococcosis was found. CNS manifestations in the patient of Pariser, Littman and Duffy (1961), in retrospect, were obviously due to cryptococcal meningitis but were misinterpreted as representing cerebral vasculitis of SLE. The confusion is understandable when it is realized that many CNS symptoms of these two disorders are similar.

Over $25 \%$ of patients with SLE present CNS involvement in the form of headaches, irritability, psychosis, meningismus seizure, etc. (Dubois and Tuffanelli, 1964). Of fifty-eight SLE cases reported by Dubois (1956), $25(43.1 \%)$ died of progressive CNS disease despite adequate steroid therapy. Twenty-seven of these fifty-eight were not autopsied, and cause of death was determined merely by a study of their terminal course. It is conceivable that a small number might have died of cryptococcal meningitis instead of so-called terminal CNS lupus. Lack of awareness of this possibility could lead one to employ even larger doses of steroids and perhaps additional immunosuppressive agents, with obviously disastrous consequences.

It should be noted that of seven patients (including our own), five had been receiving steroid therapy for periods ranging from a few weeks to several years before the infection apparently developed. In the remaining two, cryptococcal infection appeared spontaneously and treatment with prednisone for what was considered to be lupus cerebral vasculitis may have led to progressive deterioration of their condition.

Of particular importance is the fact that in five of the six cases previously reported, cryptococcal infection was not suspected, not treated and was the cause of death. Because potentially curative agents are available, cryptococcal infection must be considered in all patients with SLE who develop progressive CNS manifestations, particularly those being treated with immunosuppressive drugs.

\section{Acknowledgments}

We are indebted to Dr Mauricio J. Dulfano for his valuable advice in the preparation of this manuscript, and to Mrs Maureen Arbeeny for technical assistance.

\section{References}

CASE RePort (1961) Case records of Massachusetts General Hospital, Case 75-1961. New England Journal of Medicine, 265, 795.

Collins, D.M., Oppenheim, I.A. \& Edwards, M.R. (1971) Cryptococcosis associated with lupus erythematosusLight and electon microscopic observations. Archives of Pathology, 91, 78.

Collins, J.V., Tong, D., Bucknall, R.G. \& Warin, A.P. (1972) Cryptococcal meningitis as a complication of systemic lupus erythematosus treated with systemic corticosteroids. Postgraduate Medical Journal, 48, 52.

DuboIs, E.L. (1956) Systemic lupus erythematosus: Recent advances in its diagnosis and treatment. Annals of Internal Medicine, 45, 163.

Dubois, E.L. \& Tuffanelli, D.L. (1964) Systemic manifestations of systemic lupus erythematosus: Computer analysis of 520 cases. Journal of the American Medical Association, 190, 104.

Goldstein, E. \& Rambo, O.N. (1962) Cryptococcal infection following steroid therapy. Annals of Internal Medicine, 56. 114.

Harvey, A.M., Shulman, L.E., Tumulty, P.A. \& Conley C.C. (1954) Systemic lupus erythematosus: Review o literature and clinical analysis of 138 cases. Medicine, 33 291.

Nichols, D.R. \& MaRTin, W.J. (1955) Cryptococcosis Clinical features and differential diagnosis. Annals of Internal Medicine, 43, 767.

Pariser, S., Littman, M.L. \& Duffy, J.L. (1961) Cryptococcal meningoencephalitis associated with systemic lupus erythematosus. Journal of the Mount Sinai Hospital, N.Y., $28,550$.

Pillay, V.K.G., Wilson, D.M., Ing, T.S. \& KarK, R.M. (1968) Fungus infection in steroid-treated SLE. Journal of the American Medical Association, 205, 261.

Pillay, V.K.G., Wilson, D.M. et al. (1968) Fungus infection in steroid-treated SLE. Journal of the American Medical Association, 205, 261.

RAPAPORT, S.I., Ames, S.B., Duvall, B.J. (1960) A plasma coagulation defect in SLE arising from hypoprothrombinemia combined with antiprothrombinase activity. Blood, 15, 212.

ZIMMERMAN, L.E. \& RAPPAPORT, H. (1954) Occurrence of cryptococcosis in patients with malignant disease of reticuloendothelial system. American Journal of Clinical Pathology, 24, 1050. 